\title{
WestVirginiaUniversity
}

THE RESEARCH REPOSITORY @ WVU

West Virginia Agricultural and Forestry Experiment

Davis College of Agriculture, Natural Resources

Station Bulletins

And Design

$1-1-1968$

\section{Carcass and palatability characteristics of cattle of different ages and breeding}

James Leonard McBee

David H. Bowers

C. J. Cunningham

Follow this and additional works at: https://researchrepository.wvu.edu/ wv_agricultural_and_forestry_experiment_station_bulletins

\section{Digital Commons Citation}

McBee, James Leonard; Bowers, David H.; and Cunningham, C. J., "Carcass and palatability characteristics of cattle of different ages and breeding" (1968). West Virginia Agricultural and Forestry Experiment Station Bulletins. 558T.

https://researchrepository.wvu.edu/wv_agricultural_and_forestry_experiment_station_bulletins/675 @ WVU. It has been accepted for inclusion in West Virginia Agricultural and Forestry Experiment Station Bulletins by an authorized administrator of

The Research Repository @WVU. For more information, please contact ian.harmon@mail.wvu.edu. 
Digitized by the Internet Archive in 2010 with funding from

Lyrasis Members and Sloan Foundation 
veat Virginia Un1vereits

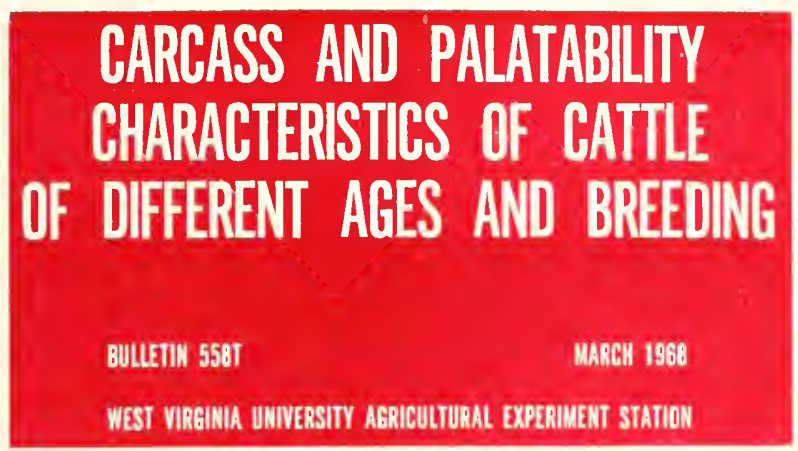




\section{THE AUTHORS}

James L. Mckee, Jr. is Associate Animal IIusbandman: David 11. Bowers was a Graduate Research Assistant at the time of this sturty; and C. J. Cunningham is Animal Ihushandman in Charge, Reymann Memorial Farms, Wardensille, W. Va.

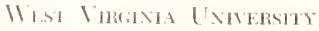

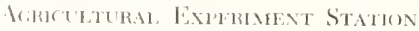

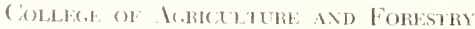

1. II. \ANLANDIVEMAM, DiRECTOR

MORGANTOWN 


\section{SUMMARY}

A study was conclucted to determine the effect of setection method. age, and sire on carcass, palatability, and chemical characteristics of beet cattle. Over a four-year puriod, sixty steer calves were chosen from each of two herds represented in this study. One herd had its sires and replacement females selected at random and the other by use of a selection index.

Sixtcen cakes from each herd were erepted white nursing dams. They were slaughtered at approximately 10 months old (calves). The remaining calves were maintained on their dans until weaned in the late fall. Sixteen additional calies from each herd were wintered on at roughage diet. grazed on pasture until the first day of July, then placed on a finishing ration until slaughtered at approximatcly 22 months old (steers). The data were analyzed within age gromps fo test for sire and selection methed differences and were then pented for testing difterences between age groups. fn addition, simple correlation coefficients were computed betwe en selected variables.

Selection method did not significantly affect any carcass charatereristies eonsidered in this stndy. Selection criteriat or selection pressure were evidently inadequate to produce differences. The stere gremp was significantly superior to the calves for careass werght, dressing per cent, marbling, carcass grache, and rib eye area. Fleese differencess are attributable to the large differences in age and weight between the two groups. Rib eye area per 100 pounds carcass weight was significantly higher and external fat thickness significantly less for the yommger age gromp.

Sires significantly affected carcass weight, rib eye area, fat thickness per 100 pounds carcass weight, and rib eye areal per 100 poumds carcats weight for steer carcasses. Dressing per cent, enformation, manlings and rib eye area of calf carcasses were significantly afteeted ly sires. Lack of agreement between age groups for sire differenes's in careass characteristics condd be due to sire groups differing in erometh patterms.

Random herd sterer carcasses produced steaks which were more tonder as measured by the taste panel than steaks fom selected hered sterer careasses. P'er cent ether extract Wals significantly higher for steahs frem selected berd steer carcasses. this difference being substantiated by higher marbling levels for the same group of carcatsses.

Juiciness, flavor, and orerall aceeptalsility were significantly lighles for steaks from steer carcitsses. Wanter-Bratoler shear values indieated steaks from stere carcasses were signilicantly more tencler than steaks from calf carcasses. Althougl tendeness ratings were non-signilicant between age gronps, ligher ratings for strahs from strer calcalse's suldstanti- 
ated 11 arner-Bratzler shear values. Per cent ether extract was significantly highler for steaks from steer earcalsse's and per cent moisture was higher in steaks from calf earcanse's, these difterencess being attributable to martolime difterences between the age groups.

Siress signitieantly intlueneed juiciness and per cent ether extract of steaks from both age groups and Warner-Bratzler shear values and per cent protein of steaks from calf earcasses. 


\title{
CARCASS AND PALATABILITY CHARACTERISTICS OF CATTLE OF DIFFERENT AGES AND BREEDING
}

\author{
JAMES L. MCBEE, JR., DAVID H. BOWERS, AND C. J. CUNNINGHAM
}

THE BEEF CATTLE INDCSTRY in West Virginia is characterized loy the cow-calf system repuiring a harge amonut of romglage. Sale of feeder calves is the main source of revenue for the beef industry.

The meat packing industry in West Virginia is small and procures a arge percentage of its beef from other areals. Iligh quality slatighter attle and carcass bee are the items most often purchased ontside the itate.

Meat packers and retailers currently desire a beef carcass which has high ratio of lean to fat and satislactory eating quality. ()f the three riterial of eating quality-tenderness, juiciness, and llanor-tendermesh is onsidered the most important. Tenderoness is influenecel by a multitude" of factors, with age loeing one of the more important, as inclicated ly the J.S.D.A. grading system.

Production of lightweight beef from calues less than ome year old hat are creep-fed while still nursing their dians, maty present an opporunity for cow-calf operators to increase production of ligh quality heol and still provide the meat packer with cattle laving a high ration af lean of fat and satisfactory eating ruality.

The purpose of this study was to compare the carcalss traits, paliatwility characteristics, and chemical composition of calues creep-fed white sursing their clanns and slaughtered at approsinately 10 momtls old with omparable cattle born at the same time, bent weanel, wintered, placed in he feedlot the following summer and fed to nombal slatrglater age of approximately 22 months. The effect of sire, year, amd leted replacement election criteriar om carcass traits and palatability (hatracteristics was also) muestigated. 


\title{
LITERATURE REVIEW
}

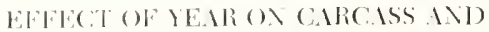 \\ P.UL \T.МBHTY CHMRACTERISTICS
}

Daillawl at al. (1964) reported significant year offects on most carcass measurements. Experimental results have shown average daily gain, staughter weight, shanghter grade, carcass weight, dressing per cent, carcass gracke, mathling score, fat thickness, and rib eyo area vary significantly from year to year (Cole et al., 1963). Ramsey et al. (1963) slinwed significant yoar effects on tendemess, juiciness, llavor, and shear force values.

\section{EFFECT (OF SIRE (M CATICASS IXH) \\ PUI, ITIBILITY CIIIR.ICTERISTICS}

In inestigation by Knapp and Nordskerg (1946) involving 177 steer calves trom 23 sires revaled heritabilities of $\$ 4,1$, and 69 per cent for carcass grade, dressing per cant, and ril, eye area, respectively. Zim (1964), in a review of literature, combined heritability estimates of other researchers and obtained the foltowing averages: carcass grade, 44 per cent; carcass weight per day of age, 25 per eent; rib eye area, 63 per cent; fat thickness, 35 per cent; and marbling, 29 per cent. Bradley et al. (ly66), comducted an ins estigation which showed sires significantly affecetel carcass woight per day of age, rib eye atrea, rib eye area per 100 keg. carcass weight, and tat thickness. Dilferences in carcass conformafim, mathlines scome and carcass grade were not significant. Jomes et al. (196:3) fonnd distinet sire differences in tenderness, juiciness, and flasor when they stuklied line sire gromps, each containing tive or six animals slanglitered at $10(0)$ porunds live weight.

\section{IEFECT (OF IVIMIL ICE ( \ CARCASS IND \\ P'II.ITIBIIIT CIIRACTERISTICS}

Ilemricksem and Yoore (1965) compared 40 steres and females of fomr atgo gromps $(6,15,42$ and 90 months $)$. Tenderness, detcrmined by a taste panel, was signilicantly different for age groups, decreasing as age increased. Niamer-Brather shear values indieated 6-month old cattle wree less touder than SS-momith old but more tender than 42- and 90month ofd cattle. No dilferences in 1 inor and juiciness dne to age were. (telected. Findel at al. (1966) conducted a study involving st steers and fomaks ranging in ace from 300 to 699 days. Taste pamel results showed oleler cattle were smperien to yemeger cattle in tendermess, juiciness, and flaver. Fenmerer cattle were more tender than older cattle as detemined 
by Wamer-Bratzler shear values. Least squares estimates indieated age had a non-significant effect on tenderness, jniciness, llavor, and shear values when marbling was held constant. Romans of al. (1965) conducted a study involving 80 beef ribs from cartasses of four maturity levels (A. $B, C$ and D). Taste panel results indicated rilos of D maturity careasses were signifieantly less tender than ribs of the older maturities, with no significant differences among the other maturities.

\section{EXPERIMENTAL PROCEDURE}

Two cow herds were maintitined at the Reyman Memorial Fams, Wardensville, West Virginia, a sub-station of the West Virginia University Agrieultural Experiment Station. The experiment began in the spring of 1962 and was teminated in the winter of 1966.

The two herds at this sub-station have been closed since 1956. In one, designated the random herd, the sires and replacement females were selected at random from each year's production. In the other, designated he selected herd, the sires and replacement lemales were selected from he annual ealf production by use of a selection index based on grade and zain.

The females from each herd were divided into two groups, each sroup being exposed to a single sire from May through fuly in order that alving would occur in Fehruary, Mards, and April. Replacement females and sires were selected in lugnst. The male calves which remained alter selection of replacement sires were castrated and divided into sire groups. From each sire group the eight highest indexing steer ealves were seected and raudomly divided into twe groups of fom tach-one gromp to xe slanghtered when approximately 10 months old and the other to be jaughtered when approximately 22 months ofd.

The calves to be slanghtered at ahout 10 months were maintained on their dams and self-fed in at creep from lugust until December.

The steers to be slaughtered at 22 montles were weaner in ()etoluer and wintered on a ration producing an anerage daty gatin of one pound per day. When pasture became available in the spring, they were grazed until placed in the feed lot alrout July 1. The steres were plased on a finishing ration and led mutil slanglatered in December.

The cattle were slanghtered at at enmunercial parking plant, where carcass data were colleceted and a shert foin purelated lor palatability mechanical, and chemicat evahnation.

\section{DARCASS ENALUITION}

All animals were weighed ane grated at the larm before shipunent te the packing plant and weiglexl upon arrival at the plant 
Each carcass was ribbed, and maturity, marlyng level, conformation grate. alsd overall eareass grate were determined according 10 U.S.D.A. Offietal Standards for Crades of Carcass Beet (I965). Numerical codes for statistical purposes were I for A maturity, 2 for B maturity, and marbling ranged from extremely abundian $=11$ to practically devoid $=1$.

Ilot carcass weights were ohtained immediately after slaughter and cold carcass werght catenlated by sulftracting eooler shrink (2.5 per cent of the loot carcass weight). Dressing per cent was calculated from the cold carcass weight and plant live weight. Extemal tat thickness and rib eye area measirements were olytained according to the procedures outlined by Ninumam (1952). Fat thickness and rib eye area per 100 pounds carcass weight were calculated.

\section{TREATMENT OF SIIORT LOINS}

The shert loins were cut through the center of the twelth rib and four 3.8 cm. steiks removed and coded A through D, beginning at the anterior end. The carcass mumber was recorded on each steak, all were wrapped in laminated freeser pitper and frozen at $-20 \mathrm{C}$ until tested.

\section{COOKI.Y PROCEDURE IND PALATABILITY TESTS}

Cooking procedure and palatability trials were conducted according to the nethed outlined by Wiles (1966).

\section{CIIEMICAL INAIMSIS}

The sample preparation was conducted as outlined by Wiles (1966) and the analyses for moisture, ether extract, and protein were made acreording to the procedures of A.O.A.C. (1960).

\section{STATISTICAL ANALASIS OF D.ITA}

There appeared to le a linear relationship between year of birth and the other varialyles in this study, theretore analysis of covariance was used to correct this sumes of variability. The mathematical model for the comlined age data was assumed to be:

where:

$$
S_{1 j k}=11+S_{11}+F_{k}+11 F_{1 k}+S F_{1 k}+b\left(X-\mu_{k}\right)+e_{1 \jmath k}
$$

Yisk Ihe measurement for the $k$ th steer from $j$ th sire in the $i$ th harerd

11. He atrotage dfeet of $i$ the herd

Si, - the average effect of $j$ th sire in $i$ th hered 
$F_{k}=$ the average effect due to $k$ th age of steer

$H F_{i k}=$ the interaction between the $i$ th leerd and the $k$ th age of steer

$S_{i j k}=$ the interaction between the $j$ th sire in $i$ th herd and the $k$ th age of steer

$\mathrm{b}=$ the regression of $\mathrm{Y}$ on $\mathrm{X}$

$\mathrm{X}=$ the year in which the calf was lorn

$\mu_{\mathrm{x}}=$ the mean of year effect on all steers represented in this study

$\mathrm{e}_{1 \jmath \mathrm{k}}=$ the random error which is assumed to be for all $i, i$, and $k$ eombinations.

The mathematical model for the within ages data was assumed to be: $Y_{1 j}=H_{1}+S_{1 j}+h\left(X-\mu_{*}\right)+t_{1 j}$

where:

$Y_{11}=$ measurement for $j$ th sire in the $i$ th herd

$I_{1}=$ the average effect of $i$ th herd

$S_{11}=$ the average effect of $j$ th sire in $i$ th hered

b = regression of $\mathrm{Y}$ in $\mathrm{X}$

$X=$ the year in whicls the calf was born

$\mu_{\mathrm{x}}=$ the mean of year effect on all steers represented in this study.

(2) $=$ the random error which is assumed to be for all $i$ and $j$ combinations.

Duncan's New Multiple Range Test (D) MVRT) was rum on all of the covariate sire means at the $\mathrm{P}<.0 .5 \mathrm{lex}$ lo detect sire differences not prodheed by the analysis of covariance.

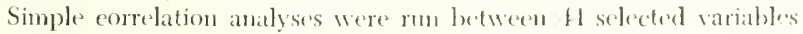
which were measured or evaluated in this study.

\section{RESULTS AND DISCUSSION}

Herd by age and sire hy age interactions were nstally significant

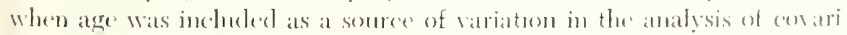

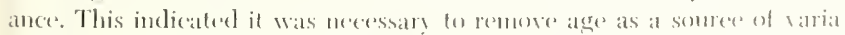

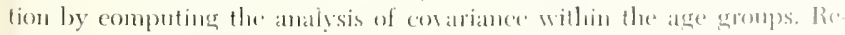
sults of both analyses are presented in the talyles and text. lum disenssion of herd differences is limited w the results of andysis within are erromps. 
Analysis of enariance was used to test the arerage difference between sires, while DX.MRT was used to detect differences between indiviclual pairs of sires. In seneral, ome would expect $1 \mathrm{~N}$ NIRT to show differences betwe'n pairs of sires that might not he apparent through use of analysis of covariances. Ordinarily, analysis of eovariance would not show signitienut difterences when DXMRT failed to detect differences between patirs of sires. However, one sire had only one progeny in the older age gromp, and when this sire was on the extreme of the arranged means, andrsis of covariance would detect significant differences where D $\backslash \backslash$ IRT would fail to doso. 1I] D D MRT were conducted at $\mathrm{P}<.05$ level of probsability. Except for the abose instance, sire differences are dis(ussed using DN.MRT results.

\section{CARCASS CIIMRACTERISTICS}

Results of combined age analysis of conariance did not show significiant herd difterences lor lirth weight, final farm grade, drift, age in days, carcass couformation, marbling, maturity, rib eye area, and external fat thickness (Talble 1). Final tarm weight was significantly ( $\mathrm{P}<.05$ ) greater for the random leed. The random herd was signifieantly $(\mathrm{P}<.01)$ superior to the selected herd tor plant weight, hot carcass weight, cold carcass weight, dressing per cent, and carcass grade as show by results of combined age analysis of covariance (Table 1 ).

IVithin age amalysis of covariance results did not reveal significant lord differences for auy variable studied (Table 1). Lack of differences hetween herds indicated selection did rot occur or the selection indes Wats mable to prodice significant differences. IJerd history shows a consiclerable momber al replacement females was reguired to replace infortile liroxd cons and, on one occasion, a selected sire of low fertility Wais replaced by a sire inferior to the infertile sire. These occurrences made improvement by selection difficult. The random and selected herds were originally obtained by randomly diving a single herd and managing the two groups as described in the experinental procedure. With a similar genetic backgromed, improsement by selection in one group in a short perion of time would be difficult to detect.

Results of combined aere analysis of covariance detected significantly: l'< (1) higher hot and cold carcass weight, dressing per cent, and earcass grate tor stree carcasses (Table 1). Steers also had significantly (P< (I) mere marbling, stemal lat, and rib eye area. Calf carcasses had a cigniticantly ( $P^{2}$ (O) larger rib eye area per 100 ponnds carcass "leight. Results did not shom signilicant diflerences between steers and calves for comlormations, matmity, or extemal fat thickness per 100 poumbls carreass woights. 


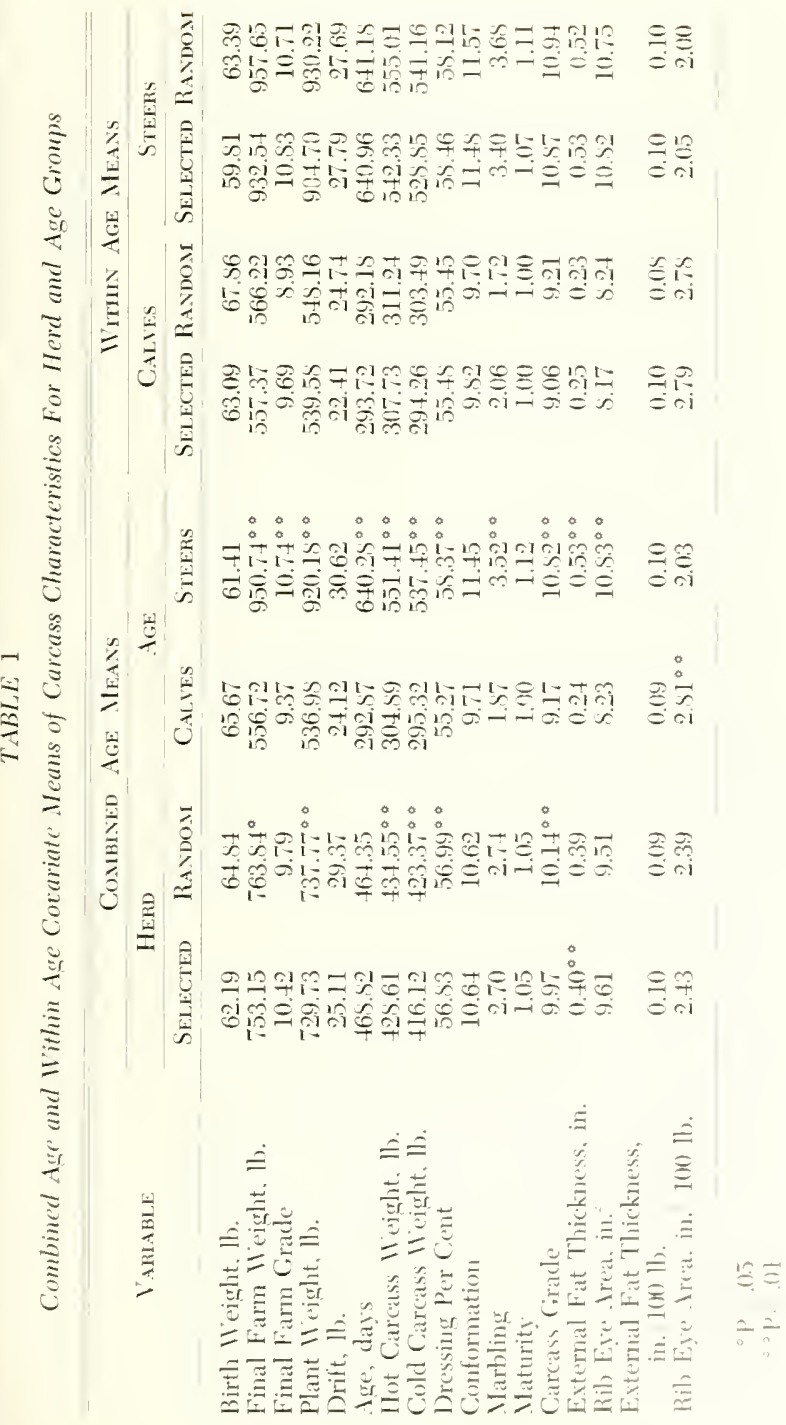


Signilicantly higher hot and cold carcass weights for steer carcasses were expected dore to large differences in age. Higher marthing levels atnd more estemal lat for steers are comparable to the results of a study by Callow (19)17). Steer carcasse's graded sulficiently higher than call tarcasses, attributahle to signilicantly higher marbling levels and higher eonformation scores. I significantly larger rib eye area for steers and a significintly larger rib eye area per 100 pomds careass weight for calves agerees with the results of Miller of al. (1965). Their work showed that as carcass weight increased rib rye area increased and rib eye area per $10 x$ pounds earcass weight decreased.

Vom-signilieant sire differences were found for all variables studied except animal age when tested by combined age analysis of covariance (Table 2). D\.Ylit of combined age covariate sire means showed sig nifieant $(\mathbf{P}<0.5)$ sire differences for birth weight, final farm weight, fina farm grate. plant weight, age in days, hot and cold carcass weights, and rib) eve areat per 100 pounds carcass weight.

Within age analvis of covariante resnlts revealed significant $(\mathrm{P}<.0 .5)$ sire clfects on final farm grade, drilt, age in lays, carcass conformation, and ribe eye area of calves. Results for steers disclosed significant dilferences in birth weiglat, final fam weight, plant weight, drift age in days, hot and cold careass weights, and rih eye area per 100 ponmels carcass weight between sire gromps.

D.M.MRT detected significant sire differences in calves for birth weight, final farm grated, dritt, age in days, dressing per cent, conformation, marhling, and rib ene area. Significant sire diflerences in steers wrere inticated h D. I.thT for bittl weight, final fam weight, final farm grade, plaut wejght, dritt, atge in days, hot and cold carcass weights. maturity, rih aye area, and fat thickness per 100 pounds carcass weight.

These lindings substantiate those of other workers previously referroced which indicate that growth and carcass traits are heritable and alford cipportmity for improvement.

\section{T.ISTE P.IVEL IVD PROXIMATE ANIIYSIS CHAR.ACTERISTICS}

Tenelerness, Haver, and overall acceptahility ratings were significantly greater for straks from random herd catrcasses as revealed by comhined ane analysis of covariance (Table 3). Steaks from selected herd carcasses latd signiticantly lower Wamer-Bratter shear values, Random lowel taratseses prodherel steaks signilicantly higher in per cent cther extract, signifieantly lower in per econt moisture, and virtually the same pro-

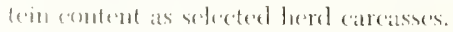

Steiks from sterer careasses had signilicantly highter juciness, flaver. ancl os rall ateerptaltility ratings as shown by eombined age analysis of 


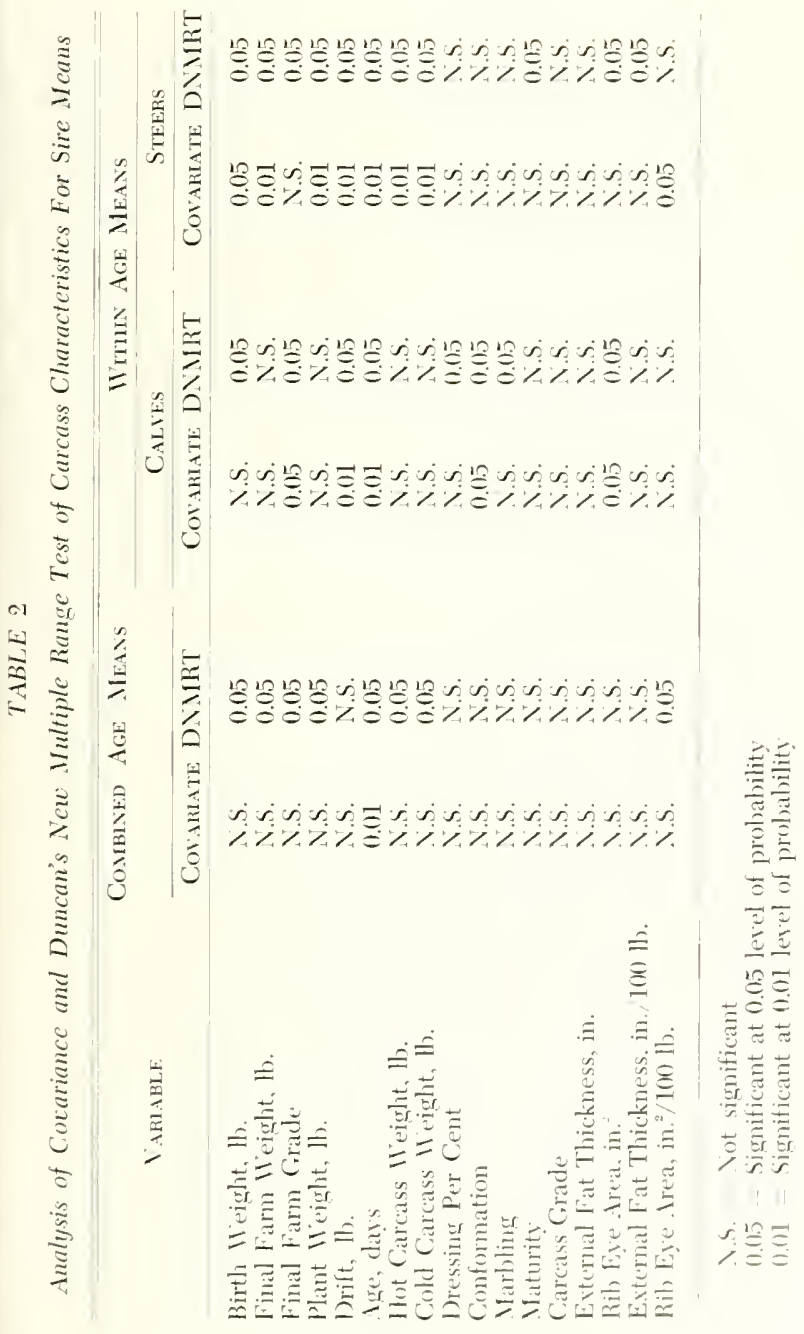




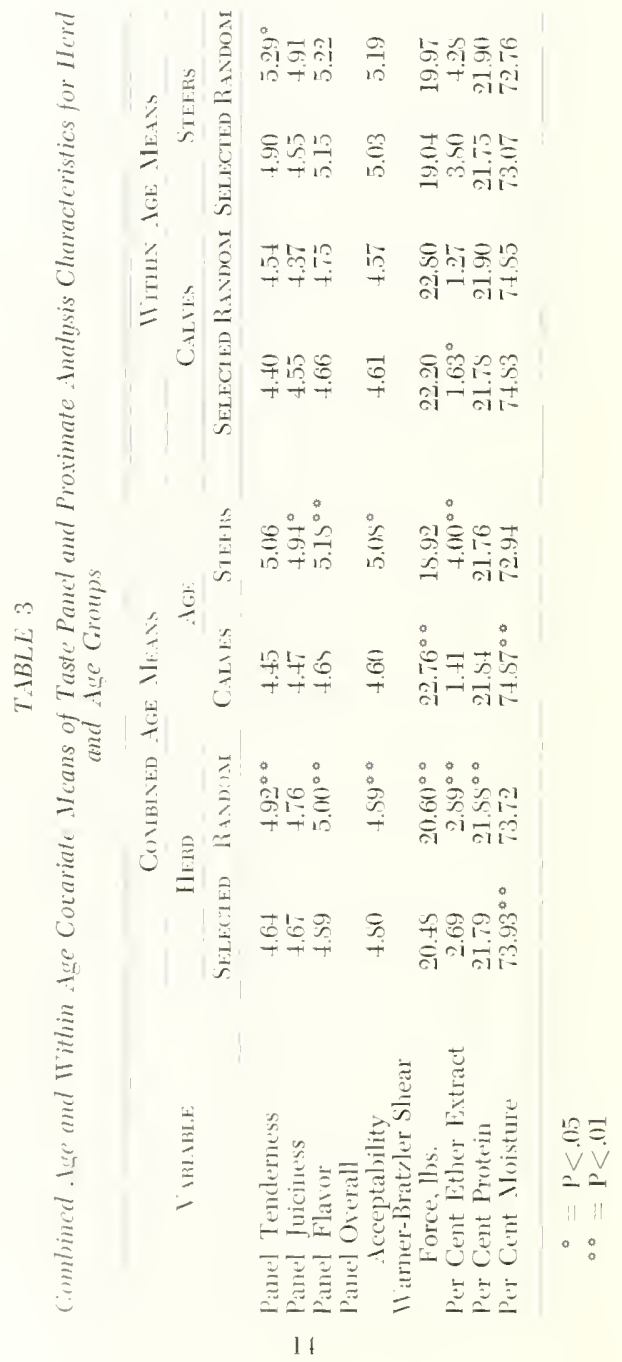


covariance, as well as significantly lower 11 anner-Bratzler slear values, indicating more acceptable tenderness. Combined age analysis of covarianee results disclosed that steaks from steer carcasses contained signiticantly higher per cent ether extract and those from calves contained significantly higher per cent moisture, while per cent protein did not ditfer significantly.

Results of combined age analysis of covatriance did not reveal signifieant sire difterences in taste pauel charateristics or Warmer-Bratzler shear values. DNMRT of combined age sire mens showed signilicant differences for 11 armer-Bratzler shear values, but unt for tatste panel ratings (Table 4 ).

Proximate analysis characteristics were not intluenced by sires, as indieated by results of combined age analysis of covariance. D\\RT revealed significant sire differences in per cent moistme only (Table 4).

Within age analysis of covariance resutts tor taste panel ratings, IV amer-Bratzler shear values, and chemical analyses of steaks $1 \mathrm{rom}$ cillt and steer eareasses did not show significant sire difterences. 1) \.ART results revealed significant sire differences in juiconess seores, WamerBratzler shear vahes, per cent ether extract, and per cent protein of steaks from calf carcasses, and in per cent ether extract of steaks from steer carcasses.

\section{RELATIONSIHIS AMONG CHEMICAL, PNL ITABJLATY, A CARCASS CHARACTERISTICS}

Correlation coefficients between if selected pairs of variables are presented in Table 5.

Careass grade was significantly correlated with dressing per cent, farm grade, and fat thickness. Since carcass grade, dressing per cent, farm grade, and fat thickness were significantly logher for sterers, 1he'se positive relationships probably are a result of differences in tat thickness between the two age groups.

It appears the correlation coetficionts in Talde 5 were groutly influenced by one factor-age at slauglater. The relationships ledwe'n per exent cther extract and marbling. carcass grade, age al slamghter, falt thickuess and rib eye area were the same in sign and approxinately the same in

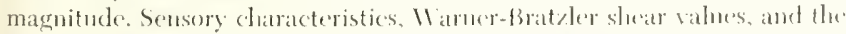
remainder of the proximate allalysis chatracteristies shem the same relationship). Marbling heds, carcass grated fat thichness, rib eye areat, and age at staugliter were signiticantly higlue for sterer carcatsses and were highly correlated with each other.

Per cont rether estratet was chrectly related to mathliug herels. catreass grade, age at statrghter, fat thickuess, atud rib eye areal. P'er cent moisture 


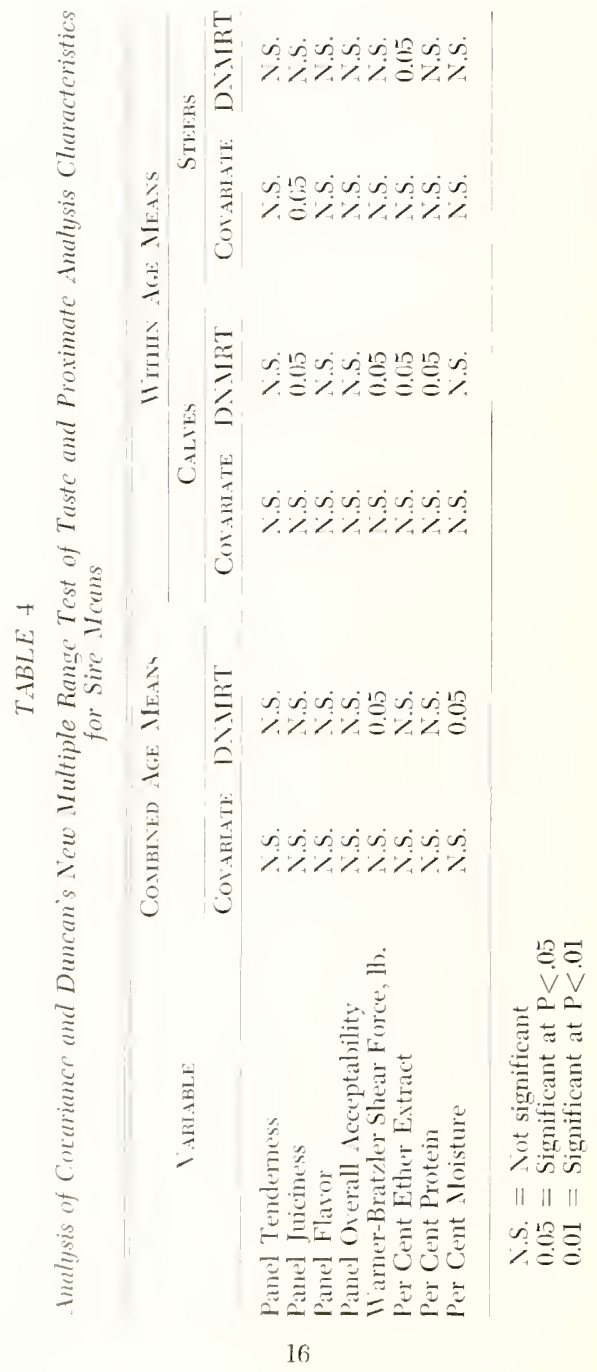


as insersely related to marbling levels, carcass grade, age at slaughter, it thickness, and rib eye area. The inverse relationship between per cent soisture and per eent ether extract can be attributed to marbling dislacing musele eells containing a much higher per cent moisture, since rarbling was highly correlated with other carcass variables.

Significant, but low correlations were computed between taste panel haracteristics and marbling levels.

Taste panel ratings were significantly related to carcass grade, age at laughter, fat thickness, and rih eye area in a pesitive manner. Waneriratzler shear values were negatively correlated with marbling levels, areass grade, age at slaughter, fat thickness, and rib eye area. These reults coincide with the correlations between taste panel tenderne'ss ratings nd the above five variables. Wamer-Bratzler shear value correlation cofficients were larger in magnitude than were panel tenderness cordation coeffieients.

\section{TABLE 5}

orrelation Coefficients for Proximate Analysis. Palatability, Careass, and Grouth Variables

\begin{tabular}{|c|c|c|}
\hline$V_{\text {ARLABLE }}$ (1) & VAR1ABLE (2) & $\mathrm{r}$ \\
\hline irth Weight & Final Farm 11 eight & $-0.1) 6$ \\
\hline arbling & Carcass Crate & $0.510^{\circ} \circ$ \\
\hline larbling & Ril, Eye Irea & $0.633^{\circ \circ}$ \\
\hline Iarbling & Extemal Fat Thickness & $0.70)^{\circ}$ \\
\hline larbling & Per Cent Ether Extract & $0.75^{\circ} \circ$ \\
\hline Iarhling & Per Cent Protein & -0.112 \\
\hline larbling & Per Cent Moristures & $-0.75^{\circ} \circ$ \\
\hline farbling & Panel Tenderness & $0.31^{\circ} \circ$ \\
\hline farbling & Panel Juiciness & $0.24^{\circ \circ}$ \\
\hline Larloling & Panel Flaver & $0.11^{\circ} \circ$ \\
\hline larbling & Panel Oxerall Acceptalility & $0.20^{\circ} \circ$ \\
\hline Iarbling & II:mer-Bratzler Shear Value's & $-0.42^{\circ 0}$ \\
\hline arcass Grade & Ril, Eye Area & $0.57^{\circ} \circ$ \\
\hline arcass Grade & External Fat Thickness & $0.66^{\circ} \circ$ \\
\hline arcass Grade & Dressing Per Cent & 0.5 .100 \\
\hline arcass Grade & Per Cont Ether Extract & $1) .67^{\circ} \circ$ \\
\hline arcass Grade. & Per Cent Protein & 0.00 \\
\hline arcass Grade & Per Cent Mloisture & $-0.70^{\circ} \circ$ \\
\hline arcass Grade & Panel Tenderness & $0.34^{\circ} 0$ \\
\hline areass Gradt' & Pantel Juicine'ss & $0.27^{\circ} \circ$ \\
\hline Garcatss Grades & Pancl listor & (). $11^{\circ} \circ$ \\
\hline arcass Grade & Pantel Oxiall Iectiptibility & $\left(1.26^{\circ} \circ\right.$ \\
\hline
\end{tabular}

(Comtinued om next page') 
Talle 5 (coutinued)

V1131.131:1: (1)

Carcass Cirade

lge al Slatugliter

dee at Slatuglater

lige at Sianghter

fye at Slangliter

Lee at Slatughiter

Ige at Slaughter

Aere at Slangliter

lese at Slaughter

Ige at Slatuglite'

lige at Slatugliter

dere at Slangliter

fue at Slanghter

Fat Thickness

Fit Thickness

Fat Thickness

Fat Thickness

Fat Thicherss

Fat Thickness

Fat Tlikkne'ss

Fat Thichuess

Ril, Ele Mrea

iiil, Eje Areais

Ril) Eye lrea

Ril, Fye Ireac

Ril, Eje liea

Ril, Eye Ireat

Ril, Eve Ireal

iiil, Eye Ireai

iib Eve Ireat

Final Farm Crade
VARIABLE: (2)

r

II ande-Bratzler Shear Values

Mirbling

Carcass Crazle

Ril) Eye Irea

Exterial Fat Thickness

Per Cent Ether Extract

Per Cent Protein

Per Cent Moisture

Pancl Tendemess

Pancl fuiciness

Panel Flavor

Pimel (Overall Acceptability

II armer-Bratzlej Shear Valiees

Per Cent Ether Extract

P'r Cent Protein

Per Cent Mloisture

Pauel Temelemess

Pautel fuiciness

Pantel Flater

Paluel Overall Acceptability

IV armer-Bratzler Shear Values

fotemal Fat Thichness

Per Cent Etles Extract

Par Cent Protein

Per Cint Maisture

Pence Tenderness

Pane] fuiciness

Pantel Flatom

Panel (),erall Acoptalility

IIarme-Bratzles Shear Values

Courcass Crade $-0.16^{\circ}$

$0.69^{\circ}$

$0.54^{\circ *}$

$0.79^{\circ} *$

$0.70^{\circ}$

0. $71^{\circ *}$

$-0.01$

$-0.67^{\circ}$ *

$0.36^{\circ \circ}$

(). $33^{\circ} \circ$

$0.45^{\circ}$

$0.41^{\circ} \circ$

$-0.42^{\circ \circ}$

$0.75^{\circ} \circ$

11.05

$-0.77^{\circ \circ}$

(). $31^{\circ \circ}$

$0.26^{\circ \circ}$

(1. $42^{\circ} \circ$

$0.35 \%$

$-0.51^{\circ \circ}$

$0.60^{\circ \circ}$

$0.64^{\circ \circ}$

0.07

$-0.61^{\circ \circ}$

$0.31^{\circ \circ}$

$0.29^{\circ \circ}$

$0.35^{\circ \circ}$

$0.34^{\circ} \circ$

$-0.43^{\circ \circ}$

$0.45^{\circ} \circ$

${ }^{\circ} \mathrm{P}<0.05$

* ${ }^{\circ} \mathrm{P}<111$ 


\section{BIBLIOGRAPHY}

3radley, N. W., L. V. Cundill, I. D. Kemp, and T. R. Cireatlouse 1966. Effects of sex and sire on performante and eareass trats of Hereford and Hereford-Red Foll calves. J. Animal Sci. 25:78.3.

Callow, E. II. 1947. Compatatioe stuclies of meat. II. The themical eomporition of latty and muscular [msue in relatem to growth ame fattening. J. Agri. Sci. 37:]13.

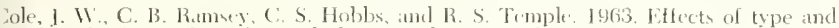
breed of British, Zelas and ditiry cattle on procluetion, palatibility and composition. I. Rate of gain, feed ifficiency and lactors alfecting market value. J. Animal sci. 22:702.

Sillarel, E. U., J. E. Legaten, T. D. Blumer. R. (i. Peternen, (). IV. Rohinson, and J.

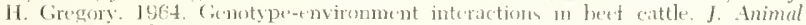
Sci. 23:54s (abstr.).

ield, R. A., G. E. Nelms and C. O. Shoononer. 1966. lifterets of age marbling and sex on palatiahility of beet. J. Animal s.r. 25:366)

lenrickion, R. L. and R. E. Afoort 1965, Effecte of animal ate on the palatability of beef. Okla. Agr. Eur. Ster. Tech. Bull. T-115.

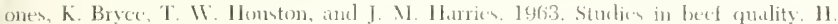

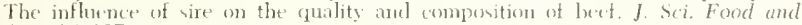
Agr. ] 1:637.

inapp, Bradtord, 1r. and Arne W. Nordskog. 1946. Itritability of live animal scores, grades and certain carcatso characteristics in locel cattle. J. Animal Sci. 5:194

liller, J. C., H. B. IIedrick, (i, B. Thompon, R, R. Freitog, WV. E. Mleyer, A. J. Dyer, and HI. D. Niumann. J965. Fatcturs affecting lompissimus dorsi and sub-

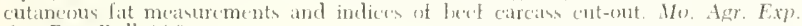
Sta. Re's. Bull. Siso.

vaumanin, II. D, 1952. A recommended proexture for meisuring and grading bert for carcass esaluation. Froc: 5th Rer. Mrat Comf. Ios.

Ramey, C. B., J. W' Cole, B. H. Meyer, and R, S. Trmple. logi3. Effects of type and hreed of British. Zelue and dairy cattle on produetion, palatalility, and composition. II. Palatability differemees and cooking loses as doternined by laboratory and Iamily panets. J. Animal Sci. 2.2:1007.

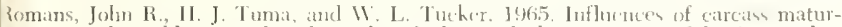
ity and marbling on the physical anel chemical eharacteristics of lowet. 1. Palatability, filxer aliameter, and proximate analyin. J. Animal Sat. 24:681.

Gim, D. Wr. I964. Interrelationships of live performance trats and quantitative and qualitative characteristics of beef carcalwes. Prose. 17th Rer. Mrat Comf. 43. 


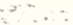



